\title{
The Imperative of Interactive Service Marketing Strategy on Customers' Satisfaction in the Contemporary Nigerian Banking Industry
}

\author{
Festus A. Nmegbu ${ }^{1} \&$ Ikechukwu F. Asiegbu ${ }^{1}$ \\ ${ }^{1}$ University of Port Harcourt, Port Harcourt, Nigeria \\ Correspondence: Festus A. Nmegbu, Department of Marketing, Faculty of Management Sciences, University of \\ Port Harcourt, Port Harcourt, Nigeria. E-mail: aleruchi1958@yahoo.com
}

Received: September 24, 2013 Accepted: October 12, $2013 \quad$ Online Published: March 24, 2014

doi:10.5539/ijms.v6n2p72 URL: http://dx.doi.org/10.5539/ijms.v6n2p72

\begin{abstract}
The internal crises in Nigerian banking industry between 2005 and 2009 manifested poor interactive relation with the customers among others; leading to failures of some banks and subsequent reforms that have recorded some improvements. This study is to examine the impact of improved interactive service marketing strategy on customers' satisfaction in contemporary Nigerian banking industry. The customers' satisfaction variables measured are service/product quality, market share, return on owners' investment and customers' loyalty. Sample size was determined using Taro Yeman's formula. Pilot survey and Cronbach's Alpha were used to confirm the validity and reliability of the study respectively and their variables of measures. Spearman's rank correlation coefficient(r), simple regression and partial correlation analyses were the statistical tools used. Consequently the following major findings among others were obtained:

(1) It was established that Interactive marketing strategy has positive and significant relationship with service/product quality; positive and moderate relationship with the market share; positive and weak relationship with return on owner's investment and positive moderate relationship with customers' loyalty. (2) There was positive and significant relationship between interactive service marketing strategy and customers' satisfaction with technology moderating them. We conclude that interactive service marketing strategy is a significant tool to embrace in Nigerian contemporary banking industry. We recommend market orientation to banks in order to increase customers' satisfaction.
\end{abstract}

Keywords: industry, improvement, interaction, service, marketing, strategy, satisfy, customer

\section{Introduction}

\subsection{Background of Problem}

This study examined the interactive marketing practices in the contemporary Nigerian banking industry and its impact in improving service delivery. Banks' burning desire to improve corporate financial goals may not be complete without incorporating interactive and relationship marketing among their corporate strategic marketing objectives. The failure to do this among others led to the 2005 to 2009 crises of size, financial inadequacies, fraud and corruption resulting in low liquidity and loss of many customers' deposits. Many banks like Savannah bank, Pan African bank, National bank failed while All-state Trust bank eventually witnessed major distress and was acquired. Standard Trust bank merged with United Bank for Africa and Intercontinental bank to form the new United Bank for Africa and Habib Bank merged with Platinum Bank to form Bank PHB (Keystone bank). The study therefore is carried out to review the impact of interactive relationship marketing on customers' satisfaction in the Nigerian banking industry.

\subsection{Statement of the Problem}

Banks were in real problem of how to cope with exposed fraud and mismanagement of resources. Hard selling, transactional marketing which revealed poor relationship marketing was practised before now. Banks did not employ enough relationship marketing skills in serving their customers. Because the customers do not judge service by its technical quality alone but also by the quality of relationship shown in dispensing them, the 
expectation of honesty, courtesy, prompt responses, fair pricing, good service encounters etc which would have been evidences of relationship marketing in banking service delivery did not take place always.

These are inconsistent with standard international banking practices. This study therefore established the relationships between interactive marketing strategy and product/service quality, market share, return on owners' investment and customers' loyalty used in the contemporary Nigerian banking industry using the following hypothesis:

(1) There is a significant relationship between interactive service marketing strategy and service/product quality, market share, return on owners' investment and customers' loyalty. Quasi experimental design used in descriptive research was employed.

(2) There is a moderating influence of technology on the relationship between interactive service marketing strategy and customers' satisfaction.

The primary data were obtained using questionnaires. The data were fitted into regression, partial regression and Spearman's rank correlation equations to establish the relationships between the variables in the hypotheses, thus the study recommends that the banking industry should sustain interactive service marketing strategy and technology application.

\section{Literature Review}

It was evident that the crises banking industry faced between 2005 and 2009 produced unfriendly relationships. These unhealthy relationships had to be changed in order for banks to cope in the contemporary market economy. The following literatures attest to this. From the 1990s to $21^{\text {st }}$ century there were capital inadequacies, size, fraud and corporate governance crises; strategies employed in trying to solve them were merger and acquisition with an improved customers' orientation. The capital base was increased to N25b and 24 banks first emerged and later 22 banks (Imala, 2005; Adam, 2005) and emphases laid on relationship marketing to achieve their goal.

\subsection{Interactive Marketing Strategy}

It includes also integrated marketing that is made up of various departments working together, communication, products and channels of distribution. In integrated marketing, satisfying of needs and surpassing of expectations are the key focus. It encourages good internal behavioural relationship. Interactive marketing meets needs and exceeds expectations of customers. It makes the frontline employees to approach customers' problems with understanding and solve them attentively thus encouraging customer relationship management (CRM) such as caring, politeness, responsiveness, honesty and keeping to appointment. Interactive service marketing approaches realize the goal of value creation by fostering relationship types of behaviours such as trust, commitment, dependability, reliability etc. It achieves the objective of increasing customers' commitment to the service company through the process of offering better value on a continuous basis at reduced cost.

In Nigerian banking industry, none interactive marketing activities such as lack of care, impoliteness, negative responses, reluctant responses, no prompt response, long service time, long waiting queues for appointment etc still subsist; these non-interactive service marketing activities have resulted in substandard core service delivery in some banks while in others they have improved. Resource advantage and distinctive capability development lead to the creation of superior customer value at a lower cost in these banks where it is practised, hence suppliers, partners and customers reduced alliances, partnering and choices respectively on their own (Moon 2000).

\subsection{Concept of Customer Satisfaction}

The word satisfaction has a range of meanings to individuals, but it generally seems to be a positive assessment of the service. It could mean contentment, happiness, relief, achieving aims, being happy with outcome and the fact that service delivery did not encounter any hassle. Thus being Happy, could mean excitement, quite contented. It could also mean feeling good or walked out grateful that the service has been satisfactory. The concept of customer satisfaction demonstrates that if experience of the service greatly exceeds the expectations clients had of the service, then satisfaction will be high, and vice versa. Customers' satisfaction is related to expectations. In the service quality literature, perceptions of service delivery are measured separately from customer expectations, and the gap between the two provides a measure of service quality.

Also in expectations and Customer Satisfaction, relief could mean thank God for a service delivery. It also means one could go with a service need and get issues sorted out without being disappointed. Expectations have a central role in influencing satisfaction with services, and these in turn are determined by a very wide range of factors. Lower expectations will result in higher satisfaction ratings for any given level of service quality. For example, poor previous experience with the service or other similar services is likely to result in being easier to pleasantly 
surprise customers. Negative preconceptions of a service provider could lead to lower expectations, but will also make it harder to achieve high satisfaction ratings, while positive preconceptions and high expectations make positive ratings more likely. Customer satisfaction could mean also achieving aims. This means realizing your aim or goal. Getting what you went for. Being successful in whatever you wanted done. To be unsatisfied is when you are still on the same level as you were before.

It is only when a customer is highly satisfied that he could be loyal to the brand hence could be retained (Ejiofor, 1977). These days, customers do not adopt one product or company for life. With easy access and global competitiveness, customers are often swayed by advertising and a chance of a better deal. Quality levels and features between competing brands and organizations are often compared before this is done. The thing that separates competitors is their level of service. It is not unusual for customers to switch back and forth between products or organizations simply because of a bad first impression from the organization personnel or lack of quality service. Happy and satisfied customers behave in a positive manner. They will buy more from the company and give a large share of their fund. Customer satisfaction is derived largely from the quality and reliability of the products and services, level of derived value, Trust and Commitment (Zeithaml \& Bitner, 2009).

\subsubsection{Courtesy}

In businesses where the underlying products have become commodity-like, quality of service depends heavily on the quality of its personnel. This is well documented in a study by Reichheld (1996) where approximately 40 percent of customers switched organizations because of what they considered to be poor service encounter. Reichheld further argued that nearly three-quarters of the banking customers mentioned courtesy as a prime consideration in choosing a bank. The study also showed that increased use of service quality/sales and professional behaviours (such as formal greetings and courtesy), improved customer satisfaction and reduced customer "flight". Indeed, customer satisfaction has for many years been perceived as key in determining why customers leave or stay with an organisation and courtesy plays a major role. Organisations need to know how to keep their customers, even if they appear to be satisfied. Reichheld (1996) suggests that unsatisfied customers may choose not to defect, because they do not expect to receive better service elsewhere. Additionally, satisfied customers may look for other providers because they believe they might receive better service elsewhere. Banks have long experience of negative encounter and poor responses, therefore the following negative encounters and poor responses to customers' service delivery are still evident in the banks-lack of care arising from pressure of work in the banks, impoliteness due to the same reason, reluctant responses, delayed responses and no responses at all. Although they claim their modern strategies have put things in shape but the truth is unclear judging from customers' complaints records. However, keeping customers is also dependent on a number of other factors. These include a wider range of product choices, greater convenience, better prices, and enhanced income (Storbacka et al, 1994).

\subsubsection{Trust}

Trust has been defined as the willingness to rely on an exchange partner whom one has confidence in his reliability and integrity (Morgan \& Hunt, 2004). Irechukwu (2000) defined trust as the customer's willingness to rely on the ability of the brand to perform its stated function. Trust causes dedication because it reduces the costs of negotiating agreements It lessens customers' fear of opportunistic behaviour by the service provider. Morgan and Hunt (2004), in social psychology, said trust is considered to consist of two elements: trust in the partner's honesty, and trust in the partner's benevolence. Honesty is the belief that a partner stands by his word, while benevolence is the belief that the partner is interested in the customer's welfare, and will not take actions with negative impact on the customer. Brand trust leads to brand loyalty and commitment because trust creates exchange relationships that are highly valued.

\subsubsection{Commitment}

Commitment is frequently defined as a desire to maintain a relationship (Deshpande 1999; Morgan \& Hunt, 2004). It is a pledge of continuity, and a resistance to change. In a conceptualization and study of employees' commitment to an organization, ALam et al. (2006) identified three types of commitment to an organization: affective, continuance and normative. Affective (or emotional) attachment exists when a strongly committed individual is involved in, and enjoys membership in an organization. Affective commitment is defined as a sentimental state of mind that is based on a person sharing, identifying with and internalizing the values of an organization which implies linking an emotional attachment (Morgan \& Hunt, 2004). Commitment in a relationship has been positioned as a central factor for customer loyalty (Chaudhuri \& Holbrook, 2002) and is a principal factor causing dedication. The Nigerian bank's service delivery lack commitment to their customers and there are trends of aggressive marketing for profit which also manifests unreliability thus a relationship that could ensure customer's 
satisfaction and sustain true profitability as the fruit is lacking. In the next section, customer's satisfaction in Nigerian banking industry will be discussed.

\subsection{Customers' Satisfaction in Nigerian Banking Industry, Interactive Dimension}

During the past decade, the financial sector has undergone dramatic changes, resulting in a market place which is characterized by intense competition, little growth in primary demand and increased deregulation. It became necessary for banks to evolve ways customers could be satisfied and retained. Customer's retention to a bank can be due to long experience of satisfactory service interaction. The degree of satisfaction can be gauged by tracking customer accounts over defined time periods and noting the degree of continuity in patronage (Lemo, 2005; Sanusi, 2010). In the new market place, the occurrence of committed relationships between a customer and his or her bank is becoming increasingly scarce. Various reasons for this have been adduced in our discussions. Many approaches have been attempted to satisfy and retain customers. This strategy among others is focusing on customers' value creation. Whether a bank pursues innovation or not makes no impact if strategic focus is not customer but product/service. In Nigeria, many banks pursue product/service orientation hence are not customers' oriented.

Thus one of the factors which have caused the customer dissatisfaction in the banking industry is that they pursue product/service innovations which cause them to begin to force or apply aggressive disparate marketing methods to make customers queue up to their products ideas which have already resulted in poor quality, unsatisfactory pricing, distrust, poor commitment among others.

Customers' orientation might be Nigerian banks' new basis for competition (Barney, 1991; Ugwu et al., 1999). The bank will start to create the customer relationship that delivers value beyond the provided core product when achieved. This involves added tangible and intangible elements to the core products, which create and enhance the "product surrounding". Banks have not yet been able to provide "up-close" personal service for customers who come with high expectations. For customers who value convenience most, banks are now offering the latest product such as electronic banking, touch-tone phone account access and internet banking. Clearly, customer value can be a strong driver of customer satisfaction (Alebiosu et al., 2004). Customer satisfaction is merely a response to the value plan offered in specific products/markets (Irechukwu, 2000). By this view, banks determine how customers define value in order to provide added-value services.

Fornell (1992), in his study of consumers, noted that although customer satisfaction and quality service appear to be important for all firms, satisfaction is more important for loyalty in industries such as banks, insurance, mail order, and automobiles. He further proposed that product differentiation is impossible in a competitive environment like the banking industry. Banks everywhere are delivering the same products. For example, there is usually only minimal difference in interest rates charged or the range of products available to customers. Bank prices are fixed and driven by the marketplace.

Customers' interactive services are all about the ability of knowledgeable, capable, and enthusiastic employees of banks to deliver the same products and services to their internal and external customers in a manner that satisfies identified and unidentified needs and ultimately results in positive word-of- mouth publicity and return business (Dawes, 1999; Leboeuf, 2000). Service quality is an essential element impacting customers' satisfaction level in the banking industry and it is embedded in interactive service marketing.

\subsection{Status of Customers' Satisfaction in Relation to Bank Interactive Service Marketing Strategies}

The Nigerian banking industry today is faced with increasing change which is caused on one hand by the recent banking industry reforms instituted by the Central Bank of Nigeria (CBN), and on the other hand by external global/ macro-economic pressures; an outcome of the world wide financial crises (Adeyemi, 2009; Barney, 1991). To succeed in this competitive marketplace, banks must formulate strategies that focus on needs, attitudes, satisfactions and behavioural patterns of the market and apply matching strategies that could bring about satisfactory service delivery. Interactive service marketing is one of them.

\subsection{Customer Retention}

Interactive marketing is essential for the life of any business and it helps in customer retention. Some customer care officers were observed not prompt, polite to customer's request despite the customer's patience in the bank. A good customer never kicks. Never nags or criticizes. And wouldn't dream of making a scene, as some people would do in public places. Such customers never come back to the bank or the service company because of bad treatment; they could take the business down the street to places where managers are smart enough to hire and train people who appreciate nice customers. Frantic spending of money on expensive advertising to get more customers instead of retaining the ones available with a few kind words, a smile, and some good service was wasteful venture to some customer service officers who wasted the banks' customers eventually (Leboeuf, 2000). 
This implied that typical business hears from only a few of its unhappy customers. The rest just quietly go away and will never come back. That means a serious financial loss for companies whose people don't know how to treat customers, and a tremendous gain to those that do.

Customers therefore quit from most banks because they are dissatisfied with the product, an attitude of indifference toward the customer by the owner, manager, or some employees (Leboeuf, 2000), who do not show humility, empathy, integrity and resilience which is ability to meet up with customers' expectation at the face of challenges.

A typical dissatisfied customer will tell people about his problem. It takes many positive service incidents to make up for one negative incident. Only few complaining customers will do business with banks again if banks resolve the complaint in their favour. If resolved on the spot, confidence will be built again. On average, a satisfied complainer will tell more people about the problem and how it was satisfactorily resolved. The average business spends more to attract new customers than it does to keep old ones. Yet customer loyalty is in most cases worth ten times the price of a single purchase.

Businesses having low service quality record average poor return on sales and lose market share per year. Businesses with high service quality record return on sales, gain market share per year and charge significantly higher prices (Leboeuf, 2000). The longer a customer stays with an organisation the more utility the customer generates (Nwankwo, 1973). This is an outcome of a number of factors relating to the time the customer spends with the organisation. These include the higher initial costs of introducing and attracting a new customer, increases in both the value and number of purchases, the customer's better understanding of the organisation, and positive word-of- mouth promotion (interactive strategy).

Apart from the benefits that the longevity of customers brings, research findings also suggest that the costs of customer retention activities are less than the costs of acquiring new customers. For example, Olalekan (2010), argued that the financial implications of attracting new customers may be five times as costly as keeping existing customers. As a consequence, retaining customers becomes a priority. However, longevity does not automatically lead to profitability.

On the other hand, consumers appear to remain loyal to the same provider, even though in many instances they hold less favourable views toward these service providers. For example, many consumers appear to perceive little differentiation between financial providers, making any change essentially worthless. Secondly, consumers appear to be motivated by convenience or inertia brought by technology (Beckett et al., 2000).

Finally, consumers associate changing banks with high switching costs in terms of the potential sacrifice and effort involved. Clearly, there are compelling arguments for bank management to carefully consider the factors that might increase customer retention rates (Marple 1999; Ahmed et al., 2003; Fisher, 2001). Other studies have focused on developing measures of customer satisfaction, customer value and customer loyalty without specifically looking into other potential meaningful areas. Examples of such areas are switching barriers, corporate image, and bank services characteristics (Ennew et al., 1996). These form the bases for the review in the next subsections.

\section{Methodology}

The research design is quasi-experimental design used in descriptive research. The cross-section sample survey of 400 banks' customers and 400 staff from the general population of 236208 and 117850 respectively (www.wikipidia.com), was carried out by administering two different sets of questionnaires. These data were measured between 2009 and 2013, the period under studied. Total population was made up of 22 banks as at the time of this study, spread in 36 states of the Federation. The study was carried out in two states of Lagos and Rivers states out of 36 states. Formula used in determining the sample size is

$$
n=N / 1+N(e)^{2}
$$

where $\mathrm{n}$ is sample size sought, 0.05 is level of significance, $\mathrm{N}$ is population size (Taro Yamen's formula for determining the sample size of heterogeneous population), (Baridam, 1999). The statistical technique used are the spearman rank correlation coefficient(r) and partial correlation; the coefficient of correlation was obtained from SPSS 17.0 output spearman rank.

\subsection{Samples of Data Presentation}

Two data tables for staff and customers of banks were used to enable the researcher learn the staff and customers' view concerning the subject matters. Areas covered include: demography of respondents and banks' profiles, descriptive analyses, statistical techniques-correlation analyses and the discussion. The demography of staff who 
responded (males/females) and banks' profiles show that $30.5 \%$ of the bank staff who responded to the questionnaires were management staff, $42 \%$ were senior staff, $13 \%$ were supervisory staff and $13.8 \%$ were junior staff and non has less than 10years of experience. All cadres of the bank staff responded and no bank was less than 20years of existence.

Table 1. Relationship between interactive/integrated marketing strategy and service/customers' loyalty using spearman rank correlation coefficient

\begin{tabular}{ll}
\hline Items & RESULTS \\
\hline Spearman rank correlation coefficient $(\mathrm{r})$ & $0.560^{++}$ \\
P- Value & 0.000 \\
Decision Criteria & $\mathrm{PV}<0.05$ \\
Decision & Accept Ha- 1 \\
\hline
\end{tabular}

Source: SPSS 17.0 output spearman rank, appendix of Research work.

\subsection{Analyses Using Spearman Rank and Partial Correlation Coefficient}

Having exhausted the hypotheses testing using the appropriate techniques, it is necessary to summarize the findings in Table 2 discuss them and make inferences:

Table 2. Summary of decisions reached

\begin{tabular}{|c|c|c|c|}
\hline Hypotheses & $\mathbf{R}$ & P-Value & Decisions \\
\hline $\begin{array}{l}\text { Ha-1: There is a significant relationship between interactive } \\
\text { service marketing strategy and service/product quality. }\end{array}$ & 0.640 & 0.000 & $\begin{array}{l}\text { Accept Ha-1: interactive service marketing } \\
\text { strategy has positive and significant relationship } \\
\text { with service/product quality. }\end{array}$ \\
\hline $\begin{array}{l}\text { Ha-2: There is a significant relationship between interactive } \\
\text { service marketing strategy and market share }\end{array}$ & 0.528 & 0.000 & $\begin{array}{l}\text { Accept Ha-2: There is a positive and moderate } \\
\text { relationship between interactive service } \\
\text { marketing strategy and market share. }\end{array}$ \\
\hline $\begin{array}{l}\text { Ha-3: There is a significant relationship between interactive } \\
\text { service marketing strategy and return on owners' investment. }\end{array}$ & 0.372 & 0.000 & $\begin{array}{l}\text { Accept Ha-3: There is a positive and weak } \\
\text { relationship between interactive service } \\
\text { marketing strategy and return on owners' } \\
\text { investment. }\end{array}$ \\
\hline $\begin{array}{l}\text { Ha-4: There is a significant relationship between interactive } \\
\text { service marketing strategy and customer' loyalty.. }\end{array}$ & 0.560 & 0.000 & $\begin{array}{l}\text { Accept Ha-4: There is a positive and moderate } \\
\text { relationship between interactive service } \\
\text { marketing strategy and customer' loyalty. }\end{array}$ \\
\hline $\begin{array}{l}\text { Ha-5: There is a significant relationship between interactive } \\
\text { service marketing strategy and customers' satisfaction. }\end{array}$ & 0.558 & 0.000 & $\begin{array}{l}\text { Accept Ha-5: There is a positive and moderate } \\
\text { relationship between interactive service } \\
\text { marketing strategy and customers' satisfaction } \\
\text { between } 2009 \text { and } 2013 \text {. }\end{array}$ \\
\hline $\begin{array}{l}\text { Ha-6:There is a moderating influence of technology on the } \\
\text { relationship between interactive service marketing strategy and } \\
\text { customer satisfaction between } 2009 \text { and } 2013\end{array}$ & $\mathrm{DPC}=$ & 0.282 & $\begin{array}{l}\text { Accept Ha-6: Technology has been moderating } \\
\text { interactive service marketing strategy and } \\
\text { customer satisfaction between } 2009 \text { and } 2013 \text {. }\end{array}$ \\
\hline
\end{tabular}

\section{Discussion of Findings}

The summary of findings has been outlined from the research results in other to arrive at conclusions that would support interactive service marketing strategies practices that enhance customers' satisfaction. They are the following: interactive service marketing strategy has positive and significant relationship with service/product quality, moderate relationship with market share, weak relationship with return on owner's investment and moderate relationship with customer loyalty. The moderating influence of technology on the relationship between interactive service marketing strategy and customer satisfaction was positive and significant.

Interactive marketing strategies are the methods or approaches used by banks' frontline staff on duty while rendering services to their customers in the bank. The Interactive marketing strategy approaches include courtesy, politeness, trustworthiness, prompt service delivery and caring. Also integrated marketing strategy means plans and programs that encourage coming together of various departments/staff of the bank to pursue the objectives of 
their organization. In practice it includes marketing, engineering/production, human resource, financial/account and audit departments as well as management, senior and junior staff working as team in the bank to satisfy the needs and surpassing of expectations of customers. This is well documented in a study by Reichheld (1996) where approximately 40 percent of customers switched organizations because of what they considered to be poor service encounter. Reichheld further argued that nearly three-quarters of the banking customers mentioned courtesy, an aspect of interactive marketing strategy as a prime consideration in choosing a bank. The study also showed that increased use of service quality, sales professional behaviours such as formal greetings and courtesy, improved customer satisfaction and reduced customer "flight". These research findings agree with his submission. Some of the banks' customers and managers' interviewed confirmed that these are common experience in their banks, especially the new generation banks which have excelled in customers' retention due to the improvement in positive service encounter (Olaleke, 2008).

On the other hand, the relationship between interactive marketing strategy and market share is positive and moderate. Market shares of some banks are influenced by some negative attitude in the bank which could not be controlled by interactive marketing strategy alone. Olaleke (2008) said unreliability (fraud) and conflicts of interest noticed among bank managers and chief executives might be responsible. He cited further that trust in the partner's honesty and trust in the partner's benevolence are integral parts of interactive marketing which was moderate in the banks according to this research finding, as measured in this work, if honesty, trust, and reliability are maintained against fraud and corruption, market share would increase significantly in the banks.

Also the relationship between interactive marketing strategy and return on owner's investment is positive and weak. Return on owner's investment should be a function of reputable business relationship and risk taking by managers of banks. Banks recorded explosive return on owners' investment between 2004 and 2007 because they took risks in the Nigerian stock market and elsewhere to make huge profits. But since 2008, the profit could not be sustained because unrelated marketing strategies among other reasons outside this study were used to pursue their financial objective; fraud and conflicts of interest, bad loans and negative encounters were noticed in the banks painting most banks black. Bad business ethics practised by some directors/bank owners accounted for the weak relationship between interactive strategy and return on owners' investment.

Finally the relationship between interactive marketing strategy and customers' loyalty is positive and moderate. Oliver (1997, 1999); Morgan and Hunt (2004) and Olayinka (2008) cited that when trust for a business partner begins to decline, confidence on that partner and his integrity becomes questionable. In this case, the customers are affected by this behaviour hence his partner's service/product brand ability to perform will no longer be trusted.

The massive deployment of technology by the banking industry between 2010 and 2013 enhanced interactive strategy application. Its moderating influence between interactive service marketing strategy and customer satisfaction is pervasive in banks' customers' value chain as cited earlier by Ugwu et al. (1999). Stephanie (2007) listed the technologies banks employ today as computer, internet, E-banking, power supply systems and ICT. Their studies agree with these research findings. They further said that Information and communications systems are major bank strategic tool which has dramatic positive impact on banking performance; because it focused on needs, attitudes, satisfactions and behavioural patterns of the market. IT is also directly impacting on interactive strategies locally in time saving, error rate reduction, enhanced management decision making, and improved speed of service delivery as perceived by the bank workers and customers interviewed. Thus managers cannot ignore Information Systems because they play a critical role in contemporary banking. Also E-banking should ordinarily bring opportunities for significant cost reduction; the capacity to rapidly re-engineer business processes; greater opportunities to sell across the borders, the potential benefits of more choice; greater competition and better value for money; more information; better tools to manage and compare information; and faster service. Thus from the foregoing discussion, the application of technology to banking practices today has enhanced interactive strategies. Furthermore, from the descriptive analyses carried out on interactive strategies using mean and scale of 5-point, prompt communication of errors in account to customers was 4.27, Attitudes of banks' workers to customers was 4.08 , response to customers' complaints was 4.10 and practise of conflict of interests was 4.27 . The staff grand mean was 4.18 and customers' grand mean was 4.03 , it could be said that Interactive/Integrated Marketing Strategy practices in the banks are more effective tool for service delivery.

The descriptive analyses of interactive marketing strategies on items of service/product quality, market shares, return on owners' investment and customers' loyalty over the period 2009-2013 revealed moderate performance for some banks and weak for others. For example, 3.90(58.75\%) staff respondents and 2.34(45.25\%) customers confirmed that service delivery is excellent in Nigerian banking industry while 2.37(45.02\%) disagreed. 
A total of $4.15(89.50 \%)$ staff and $2.47(49.15 \%)$ customers' respondents confirmed that value addition of services annually is satisfactory in the banks while $2.48(56.17 \%$ ) customers disagreed. $2.56(50.78 \%)$ staff respondents supported that the frequency of service failure is low due to interactive services while 3.95(80.12\%) customers disagreed that it is low. From the above analysis, banks interactive strategies have added non tangential values to their products/services moderately.

Also 3.16(60.2\%) respondents supported that comparatively their banks' market share is above the average range, while $2.12(40.32 \%$ ) disagreed. Also $3.85(67 \%)$ respondents confirmed that there are always integrative approaches to achieve set market share target in their bank, while $2.54(40.76 \%)$ disagreed. Those who disagreed might have experienced stock market collapse of 2007; it was evident that banks were using unconventional marketing practices to pursue their market share target. 2.80(55\%) staff respondents supported that they do experience influx of customers who express satisfaction with their banks' pattern of service delivery due to uniqueness of their relationship while 3.78(58.13\%) disagreed. Banks' interactive service delivery methods as well as their products/services quality have the capability to guarantee customers' satisfaction.

Furthermore, 2.98(60\%) staff respondents disagreed that bank's investors do express satisfaction regarding the impact of interactive strategies on the rate of return on investment while 1.89(46.73\%) respondents supported it. $3.26(69 \%)$ respondents confirmed that inquiries from investors both foreign and local show high interest in partnering with the bank while 1.74(30.01\%) disagreed. The banks' relationship marketing is core thing that could attract investors. 3.56(69\%) respondents confirmed that the banks' interactive marketing strategy added values to the return on capital investment enjoyed by the investors. While 2.4(40.8\%) disagreed. This means that return on owners' investment is moderate in some banks and low in others. 2.5(50\%) staff respondents supported that higher rate of returns customers enjoyed is linked with customers' satisfaction attributed to banks' service quality while $2.5(50 \%)$ disagreed. The banks' return on owners' investment is average. Finally $2.34(47.23 \%)$ respondents confirmed that in 2010-2013, their bank have greatly increased the value of shareholders investment due to honesty and trust built up these years, 2.66(52.77\%) disagreed because they still have a low return on owners' investment in their banks.

When data on items of customer loyalty were analysed, 3.94(88.5\%) respondents agreed not to dump their banks for another because of the banks' good relationship marketing, while 1.4(12.3\%) agreed to dump their banks for another one. This shows loyalty by the majority of the customers to their banks.

$2.21(47.50 \%)$ respondents confirmed that their banks' innovative practices in interactive practices are very appreciable while $2.03(42.17 \%)$ said their banks' innovative practices in interactive marketing are not very appreciable. 2.45(48.43\%) respondents confirmed that their banks value-added services are the best; $2.31(46 \%)$ were in disagreement. 3.5(87.50\%) respondents confirmed that they don't think any other bank has better non tangible products/services than their bank while $0.4(1.3 \%)$ people had different opinion. These analyses reveal that bank customers show loyalty to their banks, may be due to attachment, only few customers said it is due to good service delivery. From the descriptive and bivariate analyses above, banks in Nigeria moderately practise interactive service marketing strategies.

\section{Conclusion}

The study concludes that the relationship between interactive marketing strategy of Nigerian banking industry and service/products quality, market share, return on owners' investment and customers' loyalty are positive and significant, moderate, weak and moderate respectively being moderated by aggressive innovations in technology. The implication is that high interactive marketing strategy employed would turn around the ugly experiences of mistrust, fraud and corruption that characterised the banking industry from 2004-2009. Nigerian banks' introduction of strong customers and product orientation, will strengthen the weak market share and improve on the moderate return on owners' investment and customers' loyalty.

For today's banking industry to sustain growth and not fall back to the experience of 2004 to 2009: (1) Strong customers' orientation (2) Technological capabilities (3) Strong financial/fraud control measures must be put in place while interactive marketing strategy encouraged. These would bring organizational growth and profitability.

\section{Recommendations for Further Studies}

This research focused on population sample size of 400 each for banks' staffs and customers in Lagos and Rivers states respectively from the South- West and South -South geo-political zones. Future research in this area should endeavour to collect data from a bigger sample to increase the precision of the results and to enable firmer conclusions to be drawn. 
The culture, regulatory agents, Government policies customers and staff of the bank influence the implementations of strategies. To be able to mainstream the impact of environment on the implementations of bank strategies, a study should be carried out to determine the extent of the impact and recommend a way forward.

As indicated in the research design, the research contextual population was limited to 12 banks from which the findings and conclusions were based. It is entirely possible that there may be significant differences in the findings if this study is replicated using the other banks.

\section{Acknowledgements}

In pursuance of knowledge, no knowledge is proficient without initial guidance. It is dependent guidance and encouragement given by Dr. Ikechukwu Asiegbu, that enables me to complete the article.

Without restraint therefore I express my gratitude to him for such relentless efforts. I appreciate the co - operation given to me by Master Fortune Festus who coordinated the work on computer. Worth mentioning also is Mrs Blessing Nmegbu- my dear wife who stood by me during the thick and thin of this endeavour.

\section{References}

Ahmed, P. K., Rafiq, M., \& Saad, N. M. (2003). Internal marketing and the mediating role of organisational competencies. European Journal of Marketing, 37(9). http://dx.doi.org/10.1108/03090560310486960

Alam, V., \& Khokhar, B. (2006). Finance Portals for the Banking Industry, Multi-channel Operations (Remote Banking), The Regulatory Framework. Journal of Banking, 55(4).

Alebiosu, S. O., \& Omowole, S. J. (2004). The Nigeria Financial System Structure and Growth. The International Journal of Banking, 28.

Barney, J. B. (1991). Firm Resources and Sustained Competitive Advantage. Journal of Management, 17.

Beckett, A., Hewer, P., \& Howcroft, B. (2000). An Exposition of Consumer Behaviour in the Financial Services Industry. The International Journal of Bank Marketing, 18(1). http://dx.doi.org/10.1108/02652320010315325

Chaudhuri, D., \& Halbrook, N. (2002). Service Design and Delivery Strategies in Banks: Products and Service Offered by Banks, Response of Service Intangibility. The International Journal of Banking, 17(6).

Dawes, J. (1999). The Relationship between Subjective and Objective Company Performance Measures in Market Orientation Research: Further Empirical Evidence. Marketing Bulleting, 10.

Desphande, R. (1999). Developing a Market Orientation. Thousand Oaks, CA: Sage Publications.

Ejiofor, P. N. O. (1977). Bank Failures in Nigeria: Nature and Causes. The Journal of Management Studies, 9(1).

Ennew, C. T., \& Binks, M. R. (1996). The lmpact of Service Quality and Service Characteristics on Customer Retention: Small Business and their Banks in the UK. British Journal of Management, 7. http://dx.doi.org/10.1111/j.1467-8551.1996.tb00116.x

Fisher, A. (2001). Winning the Battle for Customers. Journal of Financial Services Marketing, 6(1). http://dx.doi.org/10.1057/palgrave.fsm. 4770042

Fornell, C. (1992). A National Customer Satisfaction Barometer: The Swedish Experience. Journal of Marketing. http://dx.doi.org/10.2307/1252129

Hunt, S. D., \& Morgan, S. (2004). The Resource-Advantage Theory of Competition: Dynamics, Path Dependencies, and Evolutionary Dimensions. Journal of Marketing, 60.

Imala, O. I. (2005). Consolidation in the Nigeria Banking Industry; A strategy for Survival and Development. A paper presented during the visit of the Nigerian Economy Student Association (NESA) University of Abuja Chapter.

Irechukwu, G. (2000). Enhancing the Performance of Banking Operations through Appropriate Information Technology.

Leboeuf, M. (2000). How To Win Customers And Keep Them For Life. Lagos, Nigeria: Pastoral Care Publishing.

Lemo, T. (2005). Regulatory Oversight and Stakeholder Protection. A paper presented at the BGL Mergers and Acquisitions Interactive Seminar, held at Eko Hotels and Suits V.I.

Marple, M. (1999). A Customer Retention Strategy. Mortgage Banking, 59(11). 
Moon, Y. (2000). Interactive Technologies and Relationship Marketing Strategies. Harvard Business School, (9-599-101). 63. Resources and Relationships: New Drivers of Marketing Thought 41.

Nwankwo, G. O. (1973). Traditional Banking in Developing Countries. Bankers' Magazine.

Olalekan, A. (2010). Repositioning Nigerian Banks Turbulent Entry Barriers. Journal of Banking Services, 23(3).

Olayinka, F. (2008). The Impact of E-Banking on Customers' Satisfaction. Journal of Banking Service, 13.

Oliver, S. (1999). Service Quality Metrics: Core Factors, Customer Relationship Management, Technical Quality and Functional 9000 Certification in Banking Services.

Sanusi, L. S. (2010). The Nigerian Banking Industry: What Went Wrong and the Way Forward. Lecture delivered at Bayiro University Kano.

Storbacka, K., Strandvik, R., \& Gronroos, C. (1994). Managing Customer Relationship for Profit: The Dynamics of Relationship Quality. International Journal of Service Industry Management, 5(5). http://dx.doi.org/10.1108/09564239410074358

Ugwu, L. O., Oyebisi, T. O., Ilori, M. O., \& Adagunodo, E. R. (1999). Organizational Impact of Information Technology on Banking and Insurance Sector in Nigeria. Technovation, 20(12).

Zeithami, V., Bitner, M. J., \& Gremier, D. (2009). Services Marketing: Integrating Customer-focus Across the Firm. New York: McGraw Hill.

\section{Appendix A}

\section{Part A. Customer's Responses and Bank Profile}

1. Please indicate the name of your Bank.

$\begin{array}{llll}\text { UBA } & \text { UBN } & \text { Main Street Bank } & \text { FinBank } \\ \text { Access Bank } & \text { Diamond } & \text { Zenith } & \text { First Bank } \\ \text { GT Bank } & \text { Eco Bank } & \text { Enterprise Bank } & \text { Key Stone Bank }\end{array}$

2. When did you open an account in this branch?

(a) 2005 (b) 2006 (c) 2007 (d) 2008 (e) 2009 (f) other years specify.

Part B. Customers' Assessment of the Bank Strategies and Service Delivery

Please fill in the space provided against each statement, marks to reflect your view on your bank strategy and service delivery efficiency For example, Strongly Disagree $(\mathrm{SD})=\mathbf{1},(\mathrm{D})=\mathbf{2}$, Neutral $(\mathrm{N})=\mathbf{3}$, Agree $(\mathrm{A})=\mathbf{4}$, Strongly Agree $(\mathbf{S A})=\mathbf{5}$.

\section{Research Questionnaire}

\begin{tabular}{|c|c|c|c|c|c|c|}
\hline \multirow[t]{2}{*}{$\mathrm{S} / \mathrm{n}$} & \multicolumn{6}{|l|}{ Questionnaire Items } \\
\hline & Interactive/Integrated Holistic Service Marketing & SA & A & $\mathrm{N}$ & $\mathrm{D}$ & SD \\
\hline 1 & Response to customers' complaints in your bank is prompt. & & & & & \\
\hline 2 & Errors communication by your bank to the customers is prompt. & & & & & \\
\hline 3 & $\begin{array}{l}\text { Attitudes of banks' workers to customers are excellent-polite, } \\
\text { reliable and trusted }\end{array}$ & & & & & \\
\hline \multirow[t]{2}{*}{4} & Banks ' workers do not practice conflict of interests & & & & & \\
\hline & Service/Product Quality & SA & A & $\mathrm{N}$ & $\mathrm{D}$ & SD \\
\hline 5 & Your bank's range of product offering is adequate & & & & & \\
\hline 6 & Service delivery is excellent in your branch & & & & & \\
\hline 7 & Value addition to services annually is satisfactory & & & & & \\
\hline 8 & Frequency of service failure is low & & & & & \\
\hline \multirow[t]{2}{*}{9} & Your bank exhibits high level of billing accuracy & & & & & \\
\hline & Customer Loyalty & SA & $\mathrm{A}$ & $\mathrm{N}$ & $\mathrm{D}$ & $\mathrm{SD}$ \\
\hline 10 & I am not willing to dump this bank for any other bank & & & & & \\
\hline 11 & Our bank's innovative services are very appreciable. & & & & & \\
\hline 12 & My bank's value-added services are the best of its kind. & & & & & \\
\hline 13 & Rumour of liquidation may not force me to change my bank & & & & & \\
\hline 14 & I pay very serious attention to our service information. & & & & & \\
\hline 15 & $\begin{array}{l}\text { I don't think any other bank has better products and services than } \\
\text { my bank }\end{array}$ & & & & & \\
\hline
\end{tabular}




\section{Appendix B}

\section{Questionaires}

\section{Part A. Staff Responses and Bank Profile}

1. Which of the following employment cadre do you belong?

Please tick appropriately

Management Senior Staff Supervisory Junior

2. Please indicate the name of your Bank.

UBA UBN Main Street bank Fin Bank

Access Bank Diamond Zenith First Bank

GT Bank Eco Bank Enterprise Bank Key Stone Bank

\section{Part B. Staff Assessment of the Bank Strategies and Service Delivery}

Please fill in the space provided against each statement, marks to reflect your view on your bank strategy and service delivery efficiency For example, Strongly Disagree $(S D)=1,(D)=\mathbf{2}$, Neutral $(\mathbf{N})=\mathbf{3}$, Agree $(A)=4$, Strongly Agree $(\mathrm{SA})=\mathbf{5}$.

Research Questionnaire

\begin{tabular}{|c|c|c|c|c|c|c|}
\hline \multirow[t]{2}{*}{$\mathrm{S} / \mathrm{n}$} & \multicolumn{6}{|l|}{ Questionnaire Items } \\
\hline & Interactive Service Marketing & SA & $\mathrm{A}$ & $\mathrm{N}$ & $\mathrm{D}$ & SD \\
\hline 1 & Response to customers' complaints in your bank is prompt. & & & & & \\
\hline 2 & Errors communication by your bank to the customers is prompt. & & & & & \\
\hline 3 & $\begin{array}{l}\text { Attitudes of banks' workers to customers are excellent-polite, reliable } \\
\text { and trusted }\end{array}$ & & & & & \\
\hline \multirow[t]{2}{*}{4} & Banks ' workers do not practice conflict of interests & & & & & \\
\hline & Service/Product Quality & SA & A & $\mathrm{N}$ & $\mathrm{D}$ & SD \\
\hline 5 & Your bank's range of product offering is adequate & & & & & \\
\hline 6 & Service delivery is excellent in your branch & & & & & \\
\hline 7 & Value addition to services annually is satisfactory & & & & & \\
\hline 8 & Frequency of service failure is low & & & & & \\
\hline \multirow[t]{2}{*}{9} & Your bank exhibits high level of billing accuracy & & & & & \\
\hline & Market Share & SA & A & $\mathrm{N}$ & $\mathrm{D}$ & SD \\
\hline 10 & Comparatively, my firm's market share is above the average range & & & & & \\
\hline 11 & $\begin{array}{l}\text { There is always integrative approach to achieve set market targets in } \\
\text { my bank }\end{array}$ & & & & & \\
\hline 12 & $\begin{array}{l}\text { My bank's share of the market in the banking industry is owed to the } \\
\text { unique philosophy it conveys to customers }\end{array}$ & & & & & \\
\hline 13 & $\begin{array}{l}\text { We do experience influx of customers who express satisfaction with } \\
\text { our bank's pattern of service delivery due to uniqueness of our } \\
\text { products }\end{array}$ & & & & & \\
\hline 14 & $\begin{array}{l}\text { The size of our customers increases these days in an alarming rate } \\
\text { irrespective of service failures and delay }\end{array}$ & & & & & \\
\hline 15 & $\begin{array}{l}\text { Our share of the market increases due to high patronage as a result of } \\
\text { implied benefits and values. }\end{array}$ & & & & & \\
\hline
\end{tabular}

\section{Copyrights}

Copyright for this article is retained by the author(s), with first publication rights granted to the journal.

This is an open-access article distributed under the terms and conditions of the Creative Commons Attribution license (http://creativecommons.org/licenses/by/3.0/). 